\title{
COMPLEX MONITORING AS A BASE OF ENVIRONMENTAL POLICY FORMATION AT URBAN TERRITORIES
}

\author{
Dmytro Dyadin \\ Kharkiv National Academy of Municipal Economy, Ukraine
}

\begin{abstract}
Rivers and their floodplains within urban territories are considered as principal objects of complex monitoring for cities with quite developed industry and transport as the city of Kharkiv. Flowing across both industrial and residential areas, rivers take, transport and accumulate all contaminants from surface runoff, leachate of solid wastes disposals, industrial water discharge.

In 1991 Kharkiv National Academy of Municipal Economy (NAMEK) together with Kharkiv Geological Survey carried out landscape survey and geochemical analysis of floodplains and river bed areas of main rivers within the city - Udy, Lopan and Kharkiv. Soils, bottom sediments and plants were sampled and analysed. Next stages of monitoring carried out by staff and students of NAMEK have shown considerable changes in spatial allocation of pollution sources at surveyed landscapes and quality changes of contaminants. Uncontrolled disposal of solid wastes at river banks has increased considerably during last years and the fact gives principle concern to residential and agricultural areas.

Obtained data allow making reasonable choice of runoff and wastewater treatment technologies especially phytotechnologies as innovative, low-cost and environmentally friendly treatment methods. Monitoring results should be a basement for effective industrial and municipal waste management and as a whole for forming of environmental policy at urbanized areas.
\end{abstract}

\section{KEYWORDS}

Urban areas; Geochemical and landscape survey; River ecosystems; Complex monitoring

\section{INTRODUCTION}

Urban territories are always characterized with close disposition of residential areas and industrial sites. Such "superposition" is concerned with strong pressure on human health and all components of urban ecosystems. Environmental problems are extremely actual for big urban centers like the city of Kharkiv. More than one and half million inhabitants are the subject of influence of big amount of industrial and manufacture enterprises concentrated within the city area. 


\section{GEOCHEMICAL AND LANDSCAPE SURVEY OF URBAN AREAS}

It is quite logically to put geochemical landscapes approach as a basement for understanding of urban areas contamination picture. Principally, urban landscapes can be divided into industrial, residential (1-storied and multistor) '), road, recreational, agricultural ones. Each group has its own sources of environmental p tion, geochemical migration conditions and magnitude of pressure to urban and nature ecc rstems. Geochemical investigation of urban areas implies study of pollution sources and ways of migration and accumulation of contaminants in environment.

Historically large industrial enterprises of Kharkiv are located along rivers banks. This fact and accumulative landscape characteristic may river ecosystems be one of the most vulnerable environmental components of urban areas and their condition reflects ecological problems of whole area. Small and big rivers flowing across the city area take and accumulate most types of pollutants from all sources of pollution. First of all small rivers suffer from clogging by solid wastes and chemical contamination by leachate from numerous uncontrolled open landfills. If river bottom is an area of first aquifer recharge, the problem of drinking water contamination arises since people of some residential areas use springs for potable water supply. Contaminated surface waters flow from small rivers into main rivers of the city - Kharkiv, Lopan, Udy and further to the Siverskiy Donets river, one of main drinking water supply sources of the region. Riverside soils act as buffer media accumulating a diversity of contaminants from dust and soot fall, precipitation and surface runoff. Bottom sediments are accumulation media for toxic substances with further transfer them to water. Water and riverside plants take nutrients from soils and silts providing biogeochemical migration of contaminants.

In the frames of regional geochemical and landscape survey carried out in 1991 by Kharkiv National Academy of Municipal Economy (NAMEK) and Kharkiv Geological Survey (KGS) Kharkiv area was covered with a net of sampling and landscapes description points. Sampling points were disposed along main rivers within administrative boundaries of the city. Bottom sediments, riverside soils and plants were sampled. Taking into account the fact that it was the only large-scale geochemical investigation at the region since that time, the data perform outof-date picture and may be considered only as database for study calculations and mapping.

\section{INVOLVING STUDENTS TO GEOCHEMICAL MONITORING}

The results of the research mentioned above have become an informative and valuable study material for students of Environmental Engineering and Management Department of NAMEK. For several years students follow the same survey routs and make description of landscape changes and allocation of potential and real pollution sources, take samples of soils, bottom sediments and vegetation. This research is carried out usually in 8-th semester in the frames of Environmental Geochemistry. Students perform the results in their semester papers. Papers contain calculations of coefficients of concentration, biological absorption and accumulation in different mediums, landscape maps and field photos, geochemical maps, conclusions of contamination level and health risks.

One of essential results of students' researches is revealing of new sources of surface waters pollution. Thus increasing of uncontrolled disposal of solid municipal wastes at residential 
areas gives strong concern and should be the subject of detailed examination and undertaking effective prevention measures. A lot of illegal points of sewage and industrial wastes discharge into rivers have been revealed.

\section{CONCLUSIONS}

In order to assess all potential environmental hazards and migration pathways complex landscape and geochemical monitoring should be used. Complex approach allows determining not only contamination magnitudes but reasons of processes and contribution from different sources. Thus complex geochemical monitoring of river ecosystems provides fundamental understanding of urban environment conditions and allows making reasonable steps in implementing of different municipal environmental management programs, such as municipal and industrial waste management, control of sewage and waste water outlets and others.

Involving students of KNAME to geochemical and landscape survey has turned to be quite effective tool for monitoring system especially in conditions when financing of such environmental programs is not prior item of municipal budget. Students and academy stuff in their turn are provided with study material - real objects for practical skills training. This training research in actual practice may become a part of municipal environmental monitoring program if it is approved at official level.

\section{REFERENCES}

[1] Malysheva L.L., 2000. Geokhimija Landshaftiv (Landscape Geochemistry). Lybid, Kyiv, Ukraine (in Ukrainian).

[2] Odessa State University of Ecology, 2005. Ekolologichni Problemy Regioniv Ukrajiny (Environmental Problems of Ukrainian Regions). Confer. Materials. Ekologija, Odessa, Ukraine (in Ukrainian).

[3] Alekseenko V.A., 2000. Ekologicheskaja Geokhimija (Environmental Geochemistry). Logos, Moscow, Russia, 626 p. (in Russian).

[4] Kharkiv Geological Survey, 1991. Resultaty ekologo-geokhimicheskoj sjemki goroda Kharkova (Geochemical and Landscape Survey of the City of Kharkiv). KGS, Kharkiv, Ukraine.

[5] Tsarenko D., Morokina V., Mojsuk N., Zolotareva M., Skorokhodov P., and others, 2003-2005. Landscape survey and Geochemical Analysis of rivers of Kharkiv. Students' semester papers. KNAME Kharkiv, Ukraine. 